\title{
IMPLEMENTASI PRINSIP GOOD ENVIRONMENTAL GOVERNANCE DALAM PENGELOLAAN SAMPAH DI INDONESIA
}

\author{
Hilmi Alwi Addahlawi, Umi Mustaghfiroh, Lailatul Khoirun Ni'mah, Asfiyatus \\ Sundusiyah, Ahmad Fauzan Hidayatullah
}

Program Studi Pendidikan Kimia, Fakultas Sains Dan Teknologi, Universitas Islam Negeri Walisongo Semarang, email: hilmi_1808056074@student.walisongo.ac.id

\begin{abstract}
ABSTRAK
Sudah menjadi rahasia umum bahwa permasalahan lingkungan hidup yang sering menjadi perbincangan masyarakat saat ini adalah masalah sampah. Sampah merupakan permasalahan kompleks dan serius yang dihadapi oleh banyak negara, baik negara berkembang maupun negara maju. Agar permasalahan sampah ini dapat tertangani dengan baik, maka diperlukan kerjasama antar semua anggota masyarakat baik dari pihak pemerintah, instansi swasta, maupun masyarakat pada umumnya. Kebijakan pemerintah tentang pengelolaan sampah perlu ditegakkan agar permasalahan ini dapat tertangani dengan baik. Salah satunya yaitu dengan penerapan prinsip good environmental governance dalam pengelolaan sampah. Masing-masing daerah dapat menyelenggarakan berbagai kegiatan dalam rangka pengeloaan sampah agar kelestarian lingkungan hidup tetap terjaga.
\end{abstract}

Keyword: Good environmental governance, kebijakan pemerintah, pengelolaan sampah.

\begin{abstract}
It is common knowledge about environmental problems that are often the subject of public discussion today is a waste problem. Waste is a complex and serious problem faced by many countries, both developing and developed countries. So that this waste problem can be handled properly, it is needed cooperation between all members of the community both from the government, private agencies, and the community in general. Government policies regarding waste management need to be enforced so that this problem can be handled properly. One of them is by applying the principles of good environmental governance in waste management. Each region can hold various activities in the framework of managing waste so that environmental sustainability is maintained.
\end{abstract}

Keyword: Good environmental governance, government policy, waste management. 


\section{PENDAHULUAN}

Permasalahan sampah merupakan salah satu permasalahan lingkungan hidup yang seringkali menjadi sorotan dalam masyarakat. Permasalahan ini sudah menjadi persoalan serius terutama di kotakota besar, tidak hanya di Indonesia saja, tapi di seluruh dunia. Banyak negara maju yang telah melakukan berbagai usaha untuk mengatasi masalah tersebut, akan tetapi belum memberi dampak yang signifikan.

Seiring dengan perkembangan jumlah penduduk yang semakin meningkat, maka teknologi pun juga akan semakin berkembang. Dengan perkembangan teknologi ini, maka akan tiba suatu zaman di mana berbagai barang dapat dibuat secara sintesis. Kemajuan teknologi ini juga akan berdampak pada pergeseran pola hidup masyarakat yang cenderung konsumtif dan lebih banyak menggunakan barang sintesis karena lebih mudah didapat. Ketika barang sintesis tersebut sudah tidak terpakai, maka akan berakibat munculnya barang-barang bekas yang tidak dapat terurai secara alami. Dengan demikian, dapat kita lihat bahwa peningkatan tingkat populasi, pertumbuhan ekonomi, urbanisasi yang cepat dan kenaikan standar hidup masyarakat telah mempercepat adanya penumpukan sampah (Mulasari, 2014).
DOI : doi.org/10.21009/jgg.082.04

Pengelolaan sampah menjadi permasalahan serius bagi Indonesia. Jumlah timbunan sampah yang mencapai 175.000 ton/hari atau setara dengan 64 juta ton/tahun harus dapat diolah dengan tepat agar jumlah timbunan tidak semakin meningkat. Berdasarkan hasil penelitian yang dilakukan di beberapa kota tahun 2012, pola pengelolaan sampah di Indonesia sebagai berikut: diangkut dan ditimbun di Tempat Pembuangan Akhir (TPA) (69\%), dikubur (10\%), dikompos dan didaur ulang (7\%), dibakar (5\%), dan sisanya tidak terkelola (7\%). Saat ini lebih dari 90\% kabupaten/kota di Indonesia masih menggunakan sistem open dumping, yaitu sampah dibuang begitu saja dalam sebuah tempat pembuangan akhir tanpa dikelola. Upaya pemilahan dan pengelolaan sampah masih sangat terbatas sehingga sampah tertimbun di TPA (Fitri, 2019).

Sampah yang tidak tertangani dengan baik dapat mengganggu kebersihan lingkungan, menimbulkan bau, dan mengakibatkan munculnya berbagai penyakit. Namun demikian, kesadaran masyarakat akan bahaya tersebut masih sangat rendah. Masih banyak masyarakat yang membuang sampah sembarangan atau membuangnya ke aliran sungai baik dalam skla kecil maupun skala besar. Tak hanya itu, masih banyak pabrik-pabrik yang juga membuang limbah industri ke sungai yang 
dapat mengganggu ekosistem. Pengelolaan sampah telah menjadi isu yang penting selain masalah lingkungan lainnya, terutama untuk kota- kota padat penduduk di negara-negara berkembang. Untuk menghindari dampak-dampak buruk yang ditimbulkan, maka kesadaran masyarakat akan pentingnya pengelolaan sampah harus ditingkatkan. Hal ini dapat dimulai dari penetapan kebijakan pemerintahan terhadap pengelolaan sampah. Oleh karena itu, pemerintah perlu menyediakan fasilitas pengelolaan sampah menggunakan teknologi baru agar sampah tersebut dapat ditangani dan tidak lagi menyebabkan pencemaran lingkungan membahayakan kesehatan.

\section{Konsep Good Environmental}

Governance yaitu tentang bagaimana cara kita mengelola dan berinteraksi dalam lingkungan secara konseptual. Environmental Governance menitikberatkan pada tujuan untuk memahami dan mengelola adanya hubungan timbal balik antara ekosistem dengan sistem sosial. Dalam UndangUndang No. 32 Tahun 2004 tentang Pemerintahan Daerah juga menyatakan bahwa salah satu urusan pemerintah daerah provinsi dan kabupaten/kota adalah pengendalian lingkungan hidup yang termasuk juga mengenai permasalahan sampah.

\section{PEMBAHASAN}

\section{A. Good Environmental Governance}

Good Environmental Governance merupakan bagian dari kebijakan pemerintah dalam pengelolaan lingkungan hidup demi kelestarian dan keberlanjutan lingkungan hidup. Penyelenggaraan pemerintahan berdasarkan prinsip good environmental governance memberikan makna bahwa pengelolaan urusan pemerintahan di bidang sumber daya alam dan lingkungan diselenggarakan sedemikian rupa dengan dilandasi visi perlindungan dan pelestarian fungsi lingkungan hidup dalam mendukung pelaksanaan pembangunan berkelanjutan (Nopyandri, 2011). Siahaan menyatakan bahwa prinsip Good Environmental Governance adalah dalam melaksanakan azas-azas penyelenggaraan negara yang baik maka diperlukan pengelolaan lingkungan dengan berpedoman pada keberlanjutan sumber daya (Siahaan, 2004). Sedangkan menurut World Bank dalam Belbase menyatakan bahwa kegiatan yang bertujuan untuk keberhasilan penggunaan SDA secara berkelanjutan dan menjaga kualitas lingkungan disebut Good 
Environmental Governance (Belbase, 2010). Hal tersebut membutuhkan tranparansi sistem pada institusi lingkungan, keterlibatan masyarakat dalam membentuk kebijakankebijakan dan menerapkan program. Selain itu, Budiati juga mengemukakan bahwa Good Environmental Governance merupakan kerangka pengelolaan negara berasal dari hubungan dengan rakyat dalam mengelola lingkungan hidup (Budiati, 2012). Dengan demikian, dapat disimpulkan bahwa Good Environmental Governance adalah berbagai kegiatan yang diselenggarakan oleh pemerintahan dengan tetap memperhatikan keberlangsungan dan kelestarian lingkungan hidup terutama sumber daya alam dengan melibatkan seluruh anggota masyarakat.

Dalam governance terdapat tiga komponen yang terlibat. Pertama, public governance yang merujuk pada lembaga pemerintahan. Kedua, corporate governance yang merujuk pada dunia usaha swasta. Ketiga, civil society atau masyarakat luas (Sari \& Rustan, 2009). Hubungan antar ketiga komponen tersebut harus dalam posisi seimbang, sinergis dan saling mengawasi.
Ada beberapa prinsip-prinsip dalam Good Environmental Governance. Pertama yaitu prinsip Good Environmental Governance menurut Belbase yang terdiri dari tujuh indikator yaitu sebagai berikut (Belbase, 2010):

1. Aturan hukum (the rule of law)

Aturan hukum merupakan cara untuk mengatur warga negara agar Hal ini dikarenakan hukum memiliki keluwesan dalam mengatur kehidupanematuhi peraturan atau hukum yang berlaku. Hal ini bertujuan agar penegak hukum dan masyarakat dapat berlaku sesuai dengan hukum yang berlaku dan tidak bertindak sewenang-wenang.

2. Partisipasi dan representasi (participation and representation) Partisipasi adalah keterlibatan komponen governance dalam mewujudkan tujuan yang akan dicapai baik secara fisik maupun non-fisik. Sedangkan representasi adalah pengungkapan kembali sebuah ide/gagasan dari yang telah ditangkap oleh indera dengan menggunakan bahasa sendiri.

3. Akses terhadap informasi (acces to information) 
Akses terhadap informasi merupakan perantara yang dapat digunakan untuk menerima ataupun memberikan informasi kepada publik.

4. Tranparansi dan akuntabilitas (transparency and accountability) Transparansi adalah sebuah informasi tentang laporan di lapangan, proses pengambilan keputusan dan hasil keputusan yang disampaikan dengan jelas, nyata, dan tidak dibuat-buat. Sedangkan akuntabilitas adalah bentuk pertanggungjawaban dari sebuah instansi atau lembaga.

5. Desentralisasi (decentralitation) Prinsip desentralisasi merupakan kewenangan pemerintah daerah untuk mengatur dan mengelola daerahnya sendiri.

6. Lembaga dan Institusi (institutions and agencies)

Lembaga dan institusi meruapakan organisasi yang turut berperan dalam mewujudkan tujuan yang akan dicapai. Lembaga yang dimaksud bisa lembaga pemerintah, swasta dan masyarakat.

7. Akses untuk memperoleh keadilan (acces to justice)
Artinya perantara yang digunakan untuk memperoleh kewenangan dan hak-hak yang harus diterima.

Kedua, prinsip Good Environmental Governance yang digunakan oleh Nopyandri dalam jurnal Ilmu Hukum berjudul "Penerapan Prinsip Good Environmental Governance dalam Perda Kabupaten Sleman DIY" menyebutkan terdapat enam kriteria yang digunakan yaitu transparansi, pemberdayaan masyarakat, pengakuan terhadap keterbatasan daya dukung ekosistem dan keberlanjutan, daya penegakan, desentralisasi yang demokratis, pengakuan hak masyarakat adat dan masyarakat setempat (Nopyandri, 2011).

\section{B. Pengelolaan Sampah secara Umum}

Pengelolaan sampah sangat berperan dalam menciptakan kualitas lingkungan yang bersih dan sehat. Dalam ilmu kesehatan lingkungan, pengelolaan sampah dianggap baik jika sampah tersebut tidak menjadi tempat berkembangbiaknya bibit penyakit. Beberapa syarat yang harus terpenuhi dalam pengelolaan sampah ialah tidak mencemari udara, air, dan tanah, tidak menimbulkan bau, tidak menimbulkan 
kebakaran dan lain sebagainya (Hayat \& Zayadi, 2018). Techobanoglous, 1993 mengatakan pengelolaan sampah adalah suatu bidang yang berhubungan dengan pengaturan terhadap penimbunan, penyimpanan (sementara), pengumpulan, pemindahan dan pengangkutan, pemrosesan dan pembuangan sampah dengan suatu cara yang sesuai dengan prinsip-prinsip terbaik dari kesehatan masyarakat, ekonomi, teknik (engineering), perlindungan alam (conservation), keindahan dan pertimbangan lingkungan lainnya dan juga mempertimbangkan sikap masyarakat.

Ada beberapa tahapan dalam mengelola sampah menurut Cunningham, 2004 yaitu sebagai berikut:

a. Pengolahan tahap awal :

1) Reduce (mengurangi)

2) Reuse (menggunakan kembali)

3) Recycle (mendaur ulang)

b. Pengolahan tahap akhir:

1) Sanitary landfill (penimbunan berlapis)

2) Incenaration (pembakaran)

3) Open dumping

Pengelolaan sampah juga dipengaruhi oleh beberapa faktor, diantaranya yaitu perkembangan teknologi yang pesat, peningkatan kualitas hidup, peningkatan biaya pengelolaan, operasi, dan konstruksi di berbagai bidang, teknik pengelolaan sampah, kemampuan masyarakat dalam pemeliharaan barang, lahan tempat pembuangan akhir, dan pengawasan serta penegakan peraturan.

C. Dasar Hukum Pengelolaaan Sampah

Dasar hukum pengelolaan sampah diatur dalam UU Nomor 18 Tahun 2008 tentang Pengelolaan Sampah. Berdasarkan UU tersebut dinyatakan bahwa, setiap orang mempunyai hak dan kewajiban dalam pengelolaan sampah (Saputri, 2015). Dengan berlakunya Undang-Undang Nomor 18 Tahun 2008 tersebut, maka substansi terpenting dalam pengelolaan sampah adalah bahwa semua pemerintah kabupaten/kota harus mengubah sistem pembuangan sampah menjadi sistem pengelolaan sampah. Sebagaimana tersebut dalam strategi kelima pada Peraturan Menteri Pekerjaan Umum Nomor 21 Tahun 2006 tentang Kebijakan dan Strategi Nasional Pengembangan Sistem Pengelolaan Persampahan KNSP-SPP, bahwa perlunya meningkatkan kualitas 
pengelolaan TPA ke arah sanitary landfill. Para ahli lingkungan juga merekomendasikan metode pemrosesan akhir sampah yang tepat adalah dengan metode Sanitary landfill (Mayangkara, 2016).

Pengelolaan sampah saat ini berdasarkan UU No 18 Tahun 2008 dan PP No 81 Tahun 2012 dilakukan dengan dua fokus utama yakni pengurangan dan penanganan sampah. Pengurangan sampah seperti yang dijelaskan dalam UU maupun PP yang telah disebutkan dilakukan mulai dari sumber sampah sampai pada pengelolaan akhir. Dimana pengurangan sampah diwujudkan dengan keterlibatan aktif masyarakat maupun pihak pengelola sampah. Kementerian Lingkungan Hidup mencatat rata-rata penduduk Indonesia menghasilkan sekitar $0,5 \mathrm{~kg}$ sampah per hari atau 125 juta $\mathrm{kg}$ sampah dari jumlah total penduduk Indonesia. Kondisi ini akan terus bertambah sesuai dengan kondisi lingkungannya. Data Bank Dunia menyebutkan jumlah sampah padat yang diproduksi secara nasional mencapai 151.921 juta $\mathrm{kg}$ sampah per hari, dari total sampah tersebut hanya 80 persen yang berhasil dikumpulkan, sisanya terbuang mencemari lingkungan (Kementrian
Lingkungan Hidup, 2015 dalam Hasbullah, 2019).

D. Berbagai Upaya Pengelolaan Sampah di Beberapa Daerah

Masing-masing daerah mempunyai cara tersendiri dalam mengelola sampah. Diantaranya adalah di Lingkungan Desa Sayang Jatinangor Kabupaten Sumedang yang melakukan proses daur ulang limbah agar menjadi produk baru yang memiliki nilai ekonomis. Posisi geografisnya yang relatif dekat dengan kawasan pendidikan menjadikan warganya memiliki kepekaan tinggi terhadap lingkungan. Tingginya produksi limbah rumah tangga dan perilaku negatif mengenai sampah sebenarnya merupakan persoalan yang erat kaitannya dengan perilaku budaya. Oleh sebab itu solusinya pun sebenarnya harus dikaitkan pula dengan persoalan pola pikir masyarakat tentang sampah. Daur ulang sampah agar menghasilkan produk yang mempunyai nilai ekonomis menjadi salah satu alternatif untuk mengubah pola pikir masyarakat mengenai sampah yang selama ini cenderung negatif. Kegiatan pengelolaan limbah ini dianggap berhasil karena partisipasi masyarakat 
terutama ibu-ibu rumah tangga yang cukup tinggi dan aktif dalam proses daur ulang limbah (Rijati, 2017).

Menilik ke kota Bekasi, menerapkan bank sampah sebagai sistem pengelolaan limbahnya. Bank Sampah Online Gang Gamprit dan Bank Sampah Lestari merupakan perbaduan penerapan manajemen tradisional dan modern kota tersebut. Awal berdiri bank sampah Gamprit Berseri, menerima sampah kering campuran dari masyarakat, setelah itu pengelola yang memilah, mana sampah kering yang dapat didaur ulang untuk membuat kreasi dari barang bekas, sebagian lagi mereka jual ke pengepul. Seiring dalam perkembangan Bank sampah Gamprit Berseri juga menerima sampah basah dari masyarakat yang dikelola sendiri menjadi kompos. Cara kerja yang mereka lakukan secara umum ada dua, yakni sistem individu (penabung datang ke Bank Sampah, atau dengan sistem komunal (petugas mendatangi TPS terpilah tiap RT). Dalam penerimaan sampah secara individu, biasanya masyarakat sudah memilah terlebih dahulu sampah yang berasal dari rumah tangga. Setelah itu masyarakat langsung mendatangi Bank Sampah untuk melakukan penimbangan. Kemudian dari hasil penimbangan tersebut dilakukan pencatatan di buku tabungan masyarakat yang telah diberikan kepada petugas. Sementara cara kerja sistem komunal dilakukan dengan pemilahan sampah mulai dari rumah. Kemudian tabung sampah terpilah di TPS terpilah tiap RT. Lalu petugas Bank Sampah akan mengambil sampah terpilah dari TPS RT. Sampah di TPS juga bisa diambil oleh pengepul, lalu pengepul mencatat di tabungan sampah setiap RT. Selain itu Teller memasukkan hasil penjualan tiap RT sebanyak 30\%, sementara yang $70 \%$ untuk menggaji petugas pengambil sampah. Terobosan baru Bank Sampah Online yang sudah berdiri di Kota Bekasi, diharapkan mampu mencari supplier-supplier sampah dengan mudah. Sehingga akses antrian di Bank sampah semakin berkurang (Suryani, 2016).

Beralih ke daerah Jawa Timur, yaitu kota Malang yang melakukan pengelolaan limbah dengan menerapkan Bank Sampah Malang (BSM). Dengan penduduk sebanyak 895.838 jiwa, Kota Malang memiliki potensi sampah 620 ton/hari. Sementara itu, dengan sistem pengelolaan sampah yang ada, 
timbulan sampah yang ditangani adalah 607,44 ton/hari atau $\pm 98 \%$ dari potensi timbulan yang ada. Kurang dari $2 \%$ sampah saja yang tidak terdeteksi sistem pengelolaannya. Kemungkinan sampah tersebut merupakan sampah yang dibuang dengan cara yang tidak semestinya, misal membuang ke sungai, lahan kosong, dan lainnya. Selain memberikan dampak positif bagi lingkungan, dalam proses pengelolaannya, bank sampah memiliki mekanisme relasi dan jaringan sosial yang bernilai ekonomis. BSM dapat berperan sebagai dropping point bagi produsen untuk produk dan kemasan produk yang masa pakainya telah usai. Sebagian tanggung jawab pemerintah dalam pengelolaan sampah, menjadi tanggung jawab pelaku usaha pula. Dengan menerapkan pola ini, volume sampah yang dibuang ke TPA diharapkan dapat berkurang. Aspek-aspek manajemen persampahan apabila diterapkan dengan optimal di BSM akan turut membantu pengelolaan sampah di Kota Malang. Penerapan prinsip 3R (reduce, reuse, recycle) sedekat mungkin dengan sumber sampah juga diharapkan dapat menyelesaikan masalah sampah secara terintegrasi dan menyeluruh, sehingga tujuan akhir kebijakan Pengelolaan Sampah Indonesia dapat dilaksanakan dengan baik (Suryani, 2014).

Bank sampah juga diterapkan di Tasikmalaya. Bank sampah yang diintegrasikan dengan prinsip 4R (reduce, reuse, recycle dan replant) dilaksanakan di Kampung Karangresik, Tasikmalaya, Indonesia. Kegiatan bank sampah merupakan konsep pengumpulan sampah kering dan dipilah serta memiliki manajemen layaknya perbankan tapi yang ditabung bukan uang melainkan sampah. Pemberdayaan warga melalui kegiatan penyuluhan, edukasi, pelatihan dengan metode partisipasi emansipatoris (interaksi dan komunikasi), serta dialog dengan warga di komunitas. Selain itu diperlukan dukungan kemitraan dengan membangun jejaring dan mekanisme kerja sama kelembagaan antara warga pengelola bank sampah dengan stakeholder terkait. Bank Sampah Pucuk Resik (BSPR) di Kampung Karangresik ini telah memberikan manfaat kepada warga, terutama manfaat langsung dengan berkurangnya timbulan sampah di komunitas, lingkungan menjadi lebih bersih dan asri, serta kemandirian warga secara ekonomi. Selain manfaat secara ekonomi dimana 
dari tabungan sampah memperoleh uang untuk membayar listrik dan membeli sembako, juga terwujudnya kesehatan lingkungan dengan kondisi komunitas yang lebih bersih, hijau, nyaman, dan sehat. Pengelolaan sampah terintegrasi dapat menstimulasi kreativitas dan inovasi dari masyarakat sehingga meningkatkan kesejahteraan warga (Asteria \& Heruman, 2016).

Beralih ke Sumatera, di Kota Subulussalam, metode pengelolaan sampah yang dilakukan oleh Dinas Kebersihan Kota Subulussalam adalah Metode sanitary landfill. Metode ini dengan melakukan pelapisan geotekstil yang tahan karat pada permukaan tanah sebelum ditimbuni sampah. Geoteksti berfungsi mengalirkan air lindi ke bak penampungan agar tidak mencemari tanah. Pengelolaan sampah yang dilakukan oleh Pemerintah Kota Subulussalam secara keseluruhan sudah baik hanya saja belum berwawasan lingkungan, karena pengelolaan baru sebatas menjalankan sistem pengumpulan, pengangkutan, dan pemusnahan, belum menjalankan aspek keberlanjutan misalnya belum melakukan pemisahan sampah dari sumbernya dan belum adanya tindakan pengelolaan sampah menjadi barang yang lebih berguna (Hasbullah, 2017).

Pengelolaan sampah yang baik (good garbage management) pada dasarnya merupakan tanggung jawab bersama, sehingga implementasinya tidak dapat dilihat secara sepihak pada lapisan (layer) tertentu saja. Secara umum kunci sukses pengelolaan sampah meliputi:

1. Kredibilitas para pengambil kebijakan.

2. Mekanisme implementasi yang efisien termasuk insentif terhadap pasar.

3. Perhatian yang signifikan terhadap pasar daur ulang.

4. Keterlibatan masyarakat.

5. Komitmen yang berkelanjutan terhadap kualitas yang tinggi terhadap semua operasi fasilitas pengelolaan sampah.

6. Evaluasi yang efektif terhadap strategi atau opsi yang dipilih.

Dalam rangka mengantisipasi kemungkinan kemungkinan buruk di masa depan diperlukan peraturan perundang undangan yang bersifat antisipatif, sehingga persoalanpersoalan yang akan terjadi dapat disiapkan sarana penanggulangannya sejak awal sehingga dampaknya 
terhadap kehidupan masyarakat dan lingkungan hidup dapat dieliminasi.

Disamping itu, penegakan hukum lingkungan hendaknya dilaksanakan secara konsisten, bukan hanya supaya para pencemar menjadi jera dan terhindarnya lingkungan dari risiko kerusakan dan pencemaran, tetapi juga supaya anggota masyarakat yang lain tidak melanggar hukum (prevensi umum).

\section{SIMPULAN}

Berdasarkan hasil penelitian
yang dilakukan maka penulis
menyimpulkan sebagai berikut:

1. Good Environmental Governance adalah kegiatan-kegiatan yang diselenggarakan oleh pemerintahan dengan tetap memperhatikan keberlangsungan dan kelestarian lingkungan hidup terutama sumber daya alam dengan melibatkan seluruh anggota masyarakat. Terdapat tiga komponen yang terlibat. Pertama, public governance yang merujuk pada lembaga pemerintahan. Kedua, corporate governance yang merujuk pada dunia usaha swasta. Ketiga, civil society atau masyarakat luas. Idealnya, hubungan antar ketiga komponen tersebut harus dalam posisi seimbang, sinergis dan saling mengawasi.

2. Tahapan dalam mengelola sampah menurut Cunningham, yaitu sebagai berikut:

a. Pengolahan tahap awal :

1) Reduce (mengurangi)

2) Reuse (menggunakan kembali)

3) Recycle (mendaur ulang)

b. Pengolahan tahap akhir:

1) Sanitary landfill (penimbunan berlapis)

2) Incenaration (pembakaran)

3) Open dumping

3. Dasar hukum pengelolaan sampah diatur dalam UU Nomor 18 Tahun 2008 bahwa semua pemerintah kabupaten/kota harus mengubah sistem pembuangan sampah menjadi sistem pengelolaan sampah. Sebagaimana tersebut dalam strategi kelima pada Peraturan Menteri Pekerjaan Umum Nomor 21 Tahun 2006 tentang Kebijakan dan Strategi Nasional Pengembangan Sistem Pengelolaan Persampahan KNSPSPP. Selain itu, kegiatan pengelolaan sampah dengan prinsip ramah lingkungan juga telah diatur dalam Undang - 
Undang Nomor 18 Tahun 2008 tentang pengelolaan sampah dan PP Nomor 16 Tahun 2005 tentang Sistem Penyediaan Air Minum (pasal 20).

4. Masing-masing daerah mempunyai cara tersendiri dalam mengelola sampah. Diantaranya ada yang melakukan proses daur ulang limbah agar menjadi produk baru yang memiliki nilai ekonomis, menerapkan bank sampah, da nada yang menggunakan metode sanitary landfill. Pengelolaan sampah yang baik (good garbage management) pada dasarnya merupakan tanggung jawab bersama, sehingga implementasinya tidak dapat dilihat secara sepihak pada lapisan (layer) tertentu saja.

\section{DAFTAR PUSTAKA}

Asteria, D., \& Heruman, H. (2016). Bank Sampah Sebagai Alternatif Strategi Pengelolaan Sampah Berbasis Masyarakat Di Tasikmalaya (Bank Sampah (Waste Banks) as an Alternative of Community-based Waste Management Strategy in Tasikmalaya). Jurnal Manusia dan Lingkungan, 23(1), 136-141.

Belbase, N. (2010). Good Environmental Governance In The Future Constitution.
Budiati, L. (2012). Good governance dalam pengelolaan lingkungan hidup. Ghalia Indonesia.

Cunningham, W.P. and M. A. Cunningham. 2004. Principles of Environmental Science, Second Edition. McGrawHill Co., Dubuque,IA.

Fitri, R. F., Ati, N. U., \& Suyeno, S. (2019). IMPLEMENTASI KEBIJAKAN PEMERINTAH DALAM INOVASI PENGELOLAAN SAMPAH TERPADU (Studi Kasus di Taman Tempat Pembuangan Akhir (TPA) Randegan Kota Mojokerto). Respon Publik, 13(4), 12-18.

Hasbullah, H., Ashar, T., \& Nurmaini, N. (2019).

ANALISIS

PENGELOLAAN SAMPAH DI KOTA SUBULUSSALAM. JUMANTIK (Jurnal Ilmiah Penelitian Kesehatan), 4(2), 135146.

Hayat, H., \& Zayadi, H. (2018). Model Inovasi Pengelolaan Sampah Rumah Tangga. JU-ke (Jurnal Ketahanan Pangan), 2(2), 131-141.

Mayangkara, A. P. (2016). Evaluasi Kebijakan Pengelolaan Sampah Di TPA Gunung Panggung Kabupaten Tuban. JPAP: Jurnal Penelitian Administrasi Publik, 2(02).

Mulasari, S. A., Husodo, A. H., \& Muhadjir, N. (2014). Kebijakan pemerintah dalam pengelolaan sampah domestik. Kesmas: National Public Health Journal, 8(8), 404-410.

Nopyandri, N. (2011). Penerapan Prinsip Good Environmental Governance dalam Perda Kabupaten Sleman Provinsi Daerah Istimewa YOGYAKARTA. None, 2(1). 
Rijati, S., Intan, T., \& Subekti, M. (2017). Sosialisasi Daur Ulang Sampah Sebagai Upaya Pengembangan EkoBudaya di Lingkungan Desa Sayang Jatinangor Kabupaten Sumedang. JATI EMAS (Jurnal Aplikasi Teknik dan Pengabdian Masyarakat), 1(2), 29-34.

Saputri, M. M. (2015). Evaluasi Dampak Kebijakan Pemerintah Daerah Dalam Pengelolaan Sampah Melalui Program Bank Sampah (Studi di Bank Sampah Sumber Rejeki Kelurahan Bandar Lor Kecamatan Mojoroto Kota Kediri). Jurnal Administrasi Publik, 3(11), 18041808.

Sari, M. A. P., \& Rustan, A. (2009). Implementasi Good Governance Dalam Pengelolaan Sampah. Jurnal Borneo Administrator.

Siahaan, N. H. T. (2004). Hukum lingkungan dan ekologi pembangunan. Erlangga.

Suryani, A. S. (2014). Peran bank sampah dalam efektivitas pengelolaan sampah (studi kasus bank sampah Malang). Jurnal Aspirasi, 5(1), 7184.

Suryani, E. (2016). Manajemen Pengelolaan Bank Sampah Di Kota Bekasi. JURNAL ADMINISTRASI DAN KEBIJAKAN PUBLIK, 6(1), 63-75.

Tchnobanoglous. 1993. Integreted Solid Waste Management. New York: Mc Graw Hill Inc. 